University of Nebraska - Lincoln

DigitalCommons@University of Nebraska - Lincoln

$4-2020$

\title{
Created by God and Wired to Porn: Redemptive Masculinity and Gender Beliefs in Narratives of Religious Men's Pornography Addiction Recovery
}

Kelsy Burke

Trenton M. Haltom

Follow this and additional works at: https://digitalcommons.unl.edu/sociologyfacpub

Part of the Family, Life Course, and Society Commons, and the Social Psychology and Interaction Commons

This Article is brought to you for free and open access by the Sociology, Department of at DigitalCommons@University of Nebraska - Lincoln. It has been accepted for inclusion in Sociology Department, Faculty Publications by an authorized administrator of DigitalCommons@University of Nebraska - Lincoln. 


\title{
Created by God and Wired to Porn: Redemptive Masculinity and Gender Beliefs in Narratives of Religious Men's Pornography Addiction Recovery
}

\author{
Kelsy Burke and Trenton M. Haltom \\ University of Nebraska-Lincoln, USA \\ Corresponding author - Kelsy Burke, Assistant Professor of Sociology, \\ University of Nebraska Lincoln, 742 Oldfather Hall, Lincoln, NE 68588-0324, USA; \\ email kburke@unl.edu
}

ORCID Kelsy Burke https://orcid.org/o0oo-0001-6302-4446

\begin{abstract}
The literature on hybrid masculinity suggests that some men manage subordinate or contradictory forms of masculinity while still maintaining and benefiting from gender inequality. Drawing from 35 in-depth qualitative interviews with religious participants in pornography addiction recovery programs, we expand this literature by illustrating how hybrid masculinity operates through shared cultural knowledge about sex, gender, and sexuality. We find that participants use distinct cultural schemas related to religion and science to explain how men are created by God to be biologically "hard-wired" for pornography addiction. We use the phrase redemptive masculinity to describe a type of hybrid masculinity that upholds the cultural association between hegemonic masculinity and pornography consumption, but allows religious men to describe their avoidance of pornography as a masculine feat. Redemptive masculinity depends upon particular beliefs about gender that give advantage to the religious men who work to overcome pornography addiction. We show how their stories reinforce essentialist differences between male and female

Published in Gender \& Society 34:2 (April 2020), pp 233-258.

DOI: $10.1177 / 0891243220905815$

Copyright (C) 2020 by Kelsy Burke and Trenton M. Haltom. Published by SAGE Publications. Used by permission.
\end{abstract}


bodies that protect the interests and sexual expressions of religious men. In turn, we show how hybrid masculinities may involve gender-flexible practices for men but also how these may ultimately reinforce strict and inflexible beliefs about socalled "opposite" sexes.

Keywords: men and masculinity, gender, religion, sexualities, culture

7 hough it has yet to be classified in the Diagnostic and Statisti1 cal Manual of Mental Disorders (DSM), the preeminent diagnostic tool produced by the American Psychiatric Association (2013), addiction to pornography has been described as an individual and social problem by religious organizations and leaders, activists and advocacy groups, politicians, counseling and recovery programs, and mainstream media (Oeming 2018; Stoops 2017; Voros 2009). Pornography addiction, like pornography use, is a distinctly gendered phenomenon. Controlling for other measures, national surveys have found that gender is the most significant predictor of perceived pornography addiction (Grubbs, Kraus, and Perry 2019). Sociologist Samuel Perry (2019) uses the phrase "moral incongruence" to explain why religious men in particular report negative outcomes, including addiction, of viewing porn. Because religious people, especially conservative Protestants, morally oppose pornography, they often experience guilt as a result of consuming it, even if infrequently (see also Bradley et al. 2016; Grubbs and Perry 2019). Though this work has expanded our empirical knowledge on the relationship between men, religion, and pornography, it has largely ignored the power of gender theory to explain the mechanisms by which men perceive themselves to be addicted to porn.

On the surface, it appears that men who self-identify as pornography addicts are at odds with hegemonic configurations of masculinity, or the practices and characteristics associated with idealized manhood (Connell [1987] 2005; Connell and Messerschmidt 2005). According to both empirical evidence and theories of masculinity, there is a strong relationship between hegemonic masculinity and pornography consumption in American culture (Garlick 2010; Johansson and Hammarén 2007; Pascoe 2007). Thus, men who intentionally avoid pornography do not participate in this masculinity-signifying practice. In addition, identifying as an "addict" means admitting weakness and loss of control, characteristics associated with femininity or subordinate forms of masculinity (Ezzell 2012; Travis 2009). The pornography addict, then, appears in a double-bind crisis of masculinity. 
Masculine failures, however, are inevitable because hegemonic masculinity operates as an unattainable ideal. Indeed, in the words of Raewyn Connell ([1987] 2005, 81), hegemonic masculinity "authorizes" some inconsistencies. Tristan Bridges and C. J. Pascoe (2014, 2018) have advanced the phrase "hybrid masculinity" to suggest that men, especially those with race, class, and sexual privilege, can manage subordinate or contradictory forms of masculinity while still maintaining their privileged status. They illustrate examples of hybrid masculinity from studies of mostly white, straight, and cisgender men who appear to challenge conventional gender norms or support progressive gender politics, but who simultaneously reinforce gender inequality (see Barber 2016; Bridges 2014, forthcoming; Demetriou 2001; Diefendorf 2015; Fefferman and Upadhyay 2018; McDowell 2017; Pfaffendorf 2017; Randles 2018; Schmitz and Haltom 2017). Bridges and Pascoe (2018) use both concepts- hegemonic and hybrid masculinity-to describe masculine practices and characteristics that ultimately uphold the gender order. We thus see these not as mutually exclusive, but instead as complementary and dependent.

Particularly relevant for the current study is masculinities research on religious men and men in therapeutic settings. A common theme in research on men in gender traditional religions is that they enact what Melanie Heath (2019) calls "conciliatory masculinity," which centers emotionality, intimacy, family, and friendships (typically feminine characteristics), but does not challenge the patriarchal structure of their religious traditions (see also Burke 2016; Burke and Moff Hudec 2015; Diefendorf 2015; Gerber 2016; McDowell 2017; Sumerau 2012). In therapeutic settings, much like religious ones, studies find an amalgam of conventional and nonconforming gender expectations and practices among men. Edward Flores (2014), for example, finds that gang recovery programs use expectations surrounding Chicano men's ability to provide for and protect their families to motivate change (see also Clark 2010). Other research finds that white boys and men, in particular, are encouraged to exhibit stereotypically feminine traits, such as emotional expression, modesty, and volunteerism (Ezzell 2012; Pfaffendorf 2017, 2019; Travis 2009). Jessica Pfaffendorf (2017) refers to these as "cultural tools" that are deployed in order to construct hybrid masculinity. These traits do little to challenge the gender order and often secure a racial hierarchy among white men and men of color (see also Randles 2018). 
What this literature has largely left out is how hybrid masculinities and seeming gender flexibility may in fact depend on and contribute to restrictive definitions of gender that reinforce gender inequality. In other words, although there is ample evidence of hybrid masculinity as a kind of cultural toolkit (Swidler 1986), we can examine it also as a kind of cultural knowledge. We use the case of recovery from pornography addiction. By analyzing in-depth qualitative interviews with 35 religious participants in pornography addiction recovery programs, we find that their narratives draw from both religion and science as broadly shared belief systems, or cultural schemas (Blair-Loy 2001), to explain how men are created by God to be biologically "hard-wired" for pornography addiction.

Our findings suggest that these narratives reflect hybrid masculinity because they validate the subordinate masculine practice of abstaining from pornography consumption. Yet they simultaneously depend on and reinforce particular beliefs about gendered bodies that give advantage to the religious men who work to overcome pornography addiction. We use the phrase redemptive masculinity (see also Clark 2010; Flores 2014; Pfaffendorf 2019) to describe this type of hybrid masculinity that upholds the cultural association between hegemonic masculinity and pornography consumption, but allows religious men to describe their avoidance of pornography as a masculine feat. Their stories rely on essentialist differences between male and female bodies and assumptions about men's sexual autonomy and agency, alongside women's lack thereof. That our participants are uniformly white, cisgender, and mostly heterosexual and Christian suggests that redemptive masculinity is not available to all men, but instead exists only in the context of these intersecting privileges (see also Bridges, forthcoming).

\section{Hybrid Masculinity as Cultural Configuration}

Cultural sociology extends theories of hybrid masculinity by interrogating how masculinity operates as what Orlando Patterson $(2014,20)$ calls a "cultural configuration," or "any ensemble of cultural knowledge and practices structured around a core set of values and norms motivated by a common set of interests, goals or needs." This definition matches Demetrakis Demetriou's (2001) conceptualization of 
hegemonic masculinity, an early example of the hybridization framework. Drawing from philosopher Antonio Gramsci's initial theory of hegemony as a complex power structure, Demetriou argues that hegemonic masculinity is best understood as a diverse set of masculine practices and characteristics so long as the outcome secures men's dominance. Indeed, within cultural sociology, a large body of literature demonstrates the multiple configurations of masculinity among men and boys in various cultural contexts and settings (see Flores 2014; Harding 2010; Oeur 2018; Rios 2011). Rather than supposing different cultures are homogeneous (e.g., subcultures vs. dominant culture), this work theorizes culture itself as heterogeneous, where "competing and conflicting cultural models" are always present (Harding 2010, 323).

We emphasize how individuals draw from multiple cultural schemas, or broadly shared beliefs that can interpret and narrate their ideas, choices, and behaviors (Blair-Loy 2001; Patterson 2014; Pugh 2013; Ridgeway and Correll 2004), to navigate complex and sometimes contradictory demands of masculinity. This approach demonstrates the construction of hybrid masculinity through post hoc explanations and meaning-making (see also Bridges 2014; Pfaffendorf 2017; Randles 2018; Schmitz and Haltom 2017). Though sociologists have critiqued the use of schemas and "meaning-making" as unable to explain causal mechanisms of behavior (see Patterson 2014; Vaisey 2009), we believe that investigating cultural schemas can illustrate how individuals draw from "bits of culture" (Pugh 2013, p. 48) that may appear disparate or unrelated to form coherent narratives. In other words, cultural schemas are well equipped for theories of hybrid masculinity because they allow individuals to smooth over contradictions, obscure overt forms of domination and oppression, and reinforce existing social hierarchies.

Though cultural configurations are made up of both practices and shared knowledge, we focus on the latter, examining how individuals actively participate in constructing hybrid masculinity through broadly shared beliefs about the nature of gender itself. Michael Messner (2011) specifies that essentialism-a belief in natural differences between groups-and categoricalism-that all members of a group share characteristics that members of other groups do not-shape our gender beliefs (see also Lorber 1994; Ridgeway and Correll 2004; Westbrook and Schilt 2014). Over time, the dominant gender ideology 
in the United States has shifted from what he calls "hard essentialism," which is both essentialist and categorical when it comes to gender differences, to "soft essentialism," which remains essentialist but is anticategorical in making room for women and girls to defy some feminine stereotypes. Notably, Messner argues that in the context of U.S. sports, men and boys are still largely understood through a hard essentialist lens and afforded less flexibility when it comes to gender stereotypes than women and girls (see also Messner and BozadaDeas 2009). By investigating narratives surrounding men's pornography addiction and recovery, we demonstrate how masculinity may appear flexible but still contribute to essentialist and categorical beliefs about sex, gender, and sexuality.

\section{The Rise of Pornography Addiction}

Pornography addiction recovery programs show how biological understandings of sex, gender, and sexuality help navigate the contradictory demands of religious manhood. Beginning with Alcoholics Anonymous (AA), founded in 1935, the most visible and popular model of addiction recovery has used a "disease" metaphor to gain cultural legitimacy (Travis 2009). Treating addiction as a disease removes blame from individuals for the cause of their addictions, while maintaining pressure for individuals to successfully treat and overcome their addictions (Netherland 2012; Weinberg 2002). Addiction recovery programs thus easily cater to conventional notions of masculinity and the neoliberal idea that self-control is desirable and healthy (Ezzell 2012).

Sexual addictions, including addiction to pornography, stem from the addictions movement related to substance abuse (Irvine [1990] 2005). Founded in 1977 by a longtime AA member, Sex and Love Addicts Anonymous (SLAA) was the first established sex addiction support group. In the 1990s, the addictions movement, alongside white conservative Christian leaders and organizations, began targeting pornography addiction, which they connected to both sex and Internet addiction (Perry 2019; Thomas 2013; Voros 2009). Because addiction is widely understood in modern U.S. society to be caused by biological factors (indeed, the National Institute on Drug Abuse [NIDA] describes addiction as a brain disease), supporters of this framework describe pornography addiction as having biological causes and consequences. 
For religious Americans who believe pornography consumption is morally wrong (see Grubbs, Kraus, and Perry 2019), an addictions framework suggests that consuming porn is not only sin but is also in fact a powerful physiological drive.

Blending spiritual and scientific language to both explain addiction and support recovery is consistent with other popular conservative Christian approaches to sexuality. These draw from a broader therapeutic culture that emphasizes self-fulfillment, awareness, and broad definitions of "health" that integrate physical, mental, and spiritual well-being (Burke 2016; DeRogatis 2015; Travis 2009). For example, Tom Waidzunas (2015) finds that evangelical groups have used some mainstream scientists' interest in measuring and determining "sexual orientation" as a biological category in order to advance a fringe science of "reorientation." These groups use scientific-sounding claims that align with conservative Christians' religious beliefs that homosexuality is sin (see also Gerber 2016). Authors of Christian sex advice manuals have also used language related to biology and genetics to claim evidence of "natural" sexual desires (those within heterosexual matrimony) versus transgressive ones. As Amy DeRogatis (2015) argues, popular science provides "a new vocabulary" for these evangelical writers to link sexual sin to physical damage and disease.

Some scientists have pointed out that there is less evidence supporting pornography addiction than for other behavioral addictions, such as gambling, whereas others have critiqued the science of pornography addiction for exaggerating its harms in order to admonish queer forms of sexuality and endorse heteronormativity (Oeming 2018; Stoops 2017; Voros 2009). We do not take a stand on whether pornography addiction is "real." Instead, by examining the cultural schemas surrounding people's narratives of pornography addiction, we show how pornography addiction reflects and contributes to broader and shifting beliefs about gender.

\section{Methods and Data}

Data for this article come from 35 in-depth interviews conducted by the first author in 2016 and 2017 with religious participants of both Christian and secular pornography addiction recovery programs. There is a large Christian industry made up of mostly white 
evangelical Protestant ministries and small groups, self-help books, and software programs that focus exclusively on combating pornography addiction and supporting partners (mostly wives and girlfriends) of men who use or are addicted to pornography (Perry 2019; Thomas 2013). Secular groups and organizations that use a pornography addiction frame are fewer in number than their Christian counterparts, but are nonetheless successful nonprofit and for-profit enterprises. Because highly religious people (particularly conservative Protestants) report the highest rates of pornography addiction (Grubbs, Kraus, and Perry 2019), it is likely that they are target participants for secular and Christian programs alike. We identified programs from which to recruit interview participants through a Google search for "pornography addiction recovery" and related terms. Table 1 provides details of each program. We use pseudonyms for programs and participants to maintain the confidentiality of respondents.

Starting with the help of informants at a nondenominational Protestant church in a Midwest city, we used snowball sampling strategies to recruit 13 interview participants from local groups of two national Christian pornography addiction recovery programs that we call True Intimacy and Redeemed! We recruited 22 participants from three other national programs-Church of Love, Nourish, and CleanLife-that use online platforms for self-directed resources, text-based message boards, and/or virtual group meetings. Whereas Church of Love is explicitly Christian, Nourish and CleanLife are explicitly secular. With the help of staff members of these groups, we solicited participation through a screening survey that asked participants a variety of demographic questions, including questions about religiosity, along with their interest in participating in a follow-up interview.

All interviews were one-on-one, audio-recorded and later transcribed, lasted about one hour, and were semi structured. For participants in face-to-face local programs (True Intimacy and Redeemed!), interviews were conducted in person in a private room at the church where group meetings were held. For participants in online programs, interviews were conducted over the phone. All interviews followed a similar template, asking first about how respondents decided to join a pornography addiction recovery program. Questions then focused on how respondents described using pornography, when they gained awareness that they wanted to change their behavior, and the consequences that stemmed from pornography use. To analyze interview 
Table 1. Characteristics of Pornography Addiction Recovery Programs

\begin{tabular}{|c|c|c|c|c|}
\hline Name & Type & $\begin{array}{l}\text { Primary } \\
\text { Platform }\end{array}$ & Description & $\begin{array}{r}\text { No. of Interview } \\
\text { Respondents (\% of } \\
\text { Overall Sample) }\end{array}$ \\
\hline CleanLife & Secular & Online & $\begin{array}{l}\text { Web pages with recovery strategies to avoid pornography } \\
\text { and masturbation including daily tracker and interactive } \\
\text { "challenges;" free interactive forum with user-created } \\
\text { topics and groups }\end{array}$ & $4(11)$ \\
\hline Church of Love & Christian & Online & $\begin{array}{l}\text { Blog; store selling workbooks, self-help books, and videos; } \\
\text { paid registration for online gender-segregated small groups; } \\
\text { focused on pornography addiction recovery }\end{array}$ & $4(11)$ \\
\hline Nourish & Secular & Online & $\begin{array}{l}\text { Website with self-guided recovery program focused on } \\
\text { avoiding pornography. It includes videos, journal prompts, } \\
\text { daily tracker, and accountability networks; requires paid } \\
\text { membership for adults and is free for minors }\end{array}$ & $14(40)$ \\
\hline Redeemed! & Christian & Face-to-face & $\begin{array}{l}\text { Weekly open meeting and weekly gender-segregated small } \\
\text { group study; Christian curriculum closely related to 12-step } \\
\text { programs; open to all addictions }\end{array}$ & $2(6)$ \\
\hline True Intimacy & Christian & Face-to-face & $\begin{array}{l}\text { Workbook that guides weekly gender-segregated small group } \\
\text { meetings and personal "homework" journaling exercises; } \\
\text { supports men and women who want to quit pornography } \\
\text { and women whose partners struggle with pornography }\end{array}$ & $11(31)$ \\
\hline
\end{tabular}

All names are pseudonyms.

data, we read all transcripts and wrote memos on emerging themes. After reading these memos, we developed codes and returned to the data for coding using NVivo, a qualitative data analysis software program. This iterative process involved a continual questioning, exploring, and comparing of data to understand significant themes that emerged (Corbin and Strauss 2007).

Table 2 compares participants in Christian and secular programs with the overall sample. In both types of programs, all respondents were white, almost all identified as heterosexual, and most were Christian men. The first author also interviewed seven women who participated in women-only Christian groups who either struggled with pornography use themselves $(n=1)$ or had a current or past partner they believed was addicted to pornography $(n=6)$. All participants in Christian programs were evangelical Protestant, whereas the sample from secular programs was more religiously diverse: Seven respondents were Catholic, six were Protestant, three were Latterday Saints (Mormon), and two were Jewish (see Table 2). Respondents who participated in secular programs tended to be younger (the 
Table 2. Demographic Details of Interview Sample by Program Type

\begin{tabular}{|c|c|c|c|}
\hline $\begin{array}{r}\text { No. from } \\
\text { Pro }\end{array}$ & $\begin{array}{l}\text { Christian } \\
\text { gram (\%) }\end{array}$ & $\begin{array}{l}\text { No. from Secular } \\
\text { Program (\%) }\end{array}$ & $\begin{array}{l}\text { No. of Total } \\
\text { Sample (\%) }\end{array}$ \\
\hline \multicolumn{4}{|l|}{ Age (years) } \\
\hline $19-25$ & $2(12)$ & $12(67)$ & $14(40)$ \\
\hline $26-29$ & $2(12)$ & $2(11)$ & $4(11)$ \\
\hline $30-39$ & $7(41)$ & $1(6)$ & $8(23)$ \\
\hline $40-49$ & $2(12)$ & $2(11)$ & $4(11)$ \\
\hline $50+$ & $4(24)$ & $1(6)$ & $5(14)$ \\
\hline \multicolumn{4}{|l|}{ Gender } \\
\hline Men & $10(59)$ & $18(100)$ & $28(80)$ \\
\hline Women & $7(41)$ & - & $7(20)$ \\
\hline \multicolumn{4}{|l|}{ Sexual orientation } \\
\hline Heterosexual & $16(94)$ & $17(94)$ & $33(94)$ \\
\hline Not heterosexual & $1(6)$ & $1(6)$ & $2(6)$ \\
\hline \multicolumn{4}{|l|}{ Race } \\
\hline White & $17(100)$ & $18(100)$ & $35(100)$ \\
\hline \multicolumn{4}{|l|}{ Marital status } \\
\hline Married & $10(59)$ & $5(28)$ & $15(43)$ \\
\hline Separated or divorced & $2(12)$ & - & $2(6)$ \\
\hline Never married & $5(29)$ & $13(72)$ & $18(51)$ \\
\hline \multicolumn{4}{|l|}{ Religious affiliation } \\
\hline Protestant & $17(100)$ & $6(33)$ & $23(66)$ \\
\hline Catholic & - & $7(39)$ & $7(20)$ \\
\hline Latter-day Saint & - & $3(17)$ & $3(9)$ \\
\hline Jewish & - & $2(11)$ & $2(6)$ \\
\hline \multicolumn{4}{|l|}{ Religious attendance } \\
\hline Attends church at least weekly & $16(94)$ & $14(78)$ & $30(86)$ \\
\hline Attends church less than weekly & $1(6)$ & $4(22)$ & $5(14)$ \\
\hline \multicolumn{4}{|l|}{ Prayer frequency } \\
\hline Prays at least daily & $15(88)$ & $16(89)$ & $31(89)$ \\
\hline \multirow[t]{2}{*}{ Prays less than daily } & $2(12)$ & $2(11)$ & $4(11)$ \\
\hline & $n=17$ & $n=18$ & $n=35$ \\
\hline
\end{tabular}

median age was 25, compared to 37 in the Christian programs), and therefore were less likely to be married, separated, or divorced, than respondents who participated in Christian programs. Respondents from both Christian and secular programs were highly religious: The majority reported praying at least daily and attending church regularly, though respondents who participated in secular programs attended church slightly less often.

Despite our predominantly male Protestant sample, our analysis is informed by responses from both men and women, and from multiple religious traditions: We are interested in the shared beliefs and understandings surrounding narratives of pornography addiction recovery 
that can be told by both men and women and by people whose religious beliefs may differ when it comes to specific doctrines, but who broadly share what Melinda Bollar Wagner (1997) has called "generic panconservative" beliefs related to marriage, family, and sexuality (see also Burke 2016). Although existing national studies do not report rates of perceived pornography addiction by race (e.g., Grubbs, Kraus, and Perry 2019), our unintentionally all-white sample also suggests that pornography addiction recovery programs are a kind of "white racial project" (Winant 2004), whereby whites share expectations about moral, appropriate, and good behavior based on an idealized form of whiteness or what Matthew Hughey (2010) has called "hegemonic whiteness." We found common themes when comparing male and female respondents, younger and older respondents, married and single respondents, and respondents who participated in Christian and secular support programs. We thus use these data on shared meaning-making processes (Pugh 2013).

\section{Pornography Addiction Recovery and Redemptive Masculinity}

Our analysis shows that religious pornography addiction recovery narratives construct pornography addiction as a gendered phenomenon that serves the interests of religious men. The masculinity that these narratives construct is redemptive: explaining religious men's pornography use, bolstering their masculine self-image, and reintegrating them into their religious traditions (see also Clark 2010; Flores 2014; Pfaffendorf 2019). We first describe how redemptive masculinity is constructed through religious and scientific schemas that explain why men become addicted to pornography. Next, we analyze how these schemas maintain the gender hierarchy by giving agency to men and male bodies rather than women and female bodies. Finally, we describe how these schemas mask religious men's positions of privilege by establishing them as distinct from and more nuanced than secular men who use pornography. We theorize redemptive masculinity as a kind of hybrid masculinity. It is distanced from one dimension of hegemonic masculinity in that it is critical of men's consumption of pornography, while simultaneously depending upon and contributing to essentialist understandings of differences between men and women's sexed bodies and sexualities. 


\section{Men Watching Porn: A Divine and Biological Mandate}

All respondents reported that they believed pornography consumption was morally wrong. A common explanation, especially among conservative Protestants (see also Burke 2016; Diefendorf 2015; Perry 2019), was that watching (and presumably masturbating to) pornography is a sexual sin equivalent to extramarital sex or adultery given that the viewer lusts after a sexual partner to whom they are not married. But the human capacity for sinfulness was not typically described as the reason people watch porn. Instead, all respondents used scientific vocabulary to explain men's attraction to pornography.

The vast majority of respondents (29 of 35) referred to the brain along with neurological or physiological processes they describe as being affected by pornography use. A common metaphor was that men's brains are "wired" in a way that makes them biologically preconditioned to become sexually aroused by visual stimuli. Christopher (28 years old, Protestant, True Intimacy participant) puts it this way: Pornography addiction was a "physical manifestation in my brain. . . . My brain had been wired to use pornography." Melissa (26, Protestant, True Intimacy participant), who describes her ex-fiancé, David, as a pornography addict, says that he was "really sick" and then elaborates: David watched pornography several times a day and "that's so much dopamine getting released that your brain shuts down, and then the only way to feel normal is by looking at porn." Another partner of a pornography addict, Deborah (52, Protestant, True Intimacy participant), describes it as a "sexual high" from "all the chemicals-all the endorphins going to your brain.” This language emphasizes natural biological processes, rather than language of sin or poor choices, to explain how men become addicted to pornography.

Scientific claims about the "naturalness" of men's pornography use allow respondents to avoid pathologizing religious men who use pornography. As Elliot (24, Protestant, True Intimacy group leader) explains, "I'm a believer and I'm stuck in this sin, and yeah, I feel like there is a physical component. Your mind is, like, rewired. You have pathways in your mind that are deeply entrenched and even if you are a believer in Christ, it is just hard to get out of that." While Elliot believes that he is committing a sin whenever he views pornography, he uses science to avoid internalizing shame about his actions. This emphasis on a biological explanation for sexual sin has parallels to some 
conservative Christian responses to homosexuality, but in these cases, churches often pressure LGBTQ members to express shame as a way to atone for their sexual deviation (Moon and Tobin 2018). The privileged position of straight white men who experience the sexual sin of pornography addiction instead distances themselves from blame, shame, and stigma.

Heather (49, Protestant, True Intimacy participant), a woman who describes her husband as addicted to pornography, is an illuminating example of how scientific explanations temper harsh religious reactions to men's pornography use. She explains that she once thought pornography was a "moral issue," but now understands it primarily through the lens of a biological addiction.

When I started to realize what pornography really did to the brain-I mean it really caused changes in the brain-that's when I started to get it and why it is so hard to quit. . . . I think just learning about what it did to the brain helped me to realize just exactly what I was up against. . . . It might start out as a moral issue, but it is definitely a brain issue, and an addiction issue. . . . Once I learned that, grace was much easier to show.

Heather's repeated reference to "the brain" shows how she borrows from science to construct a biological truth that confirms her moral conviction that viewing pornography is wrong. According to her, this understanding of pornography addiction as a biological condition is what enables her to perform the religious practice of "grace," or extending compassion toward her husband even while disapproving of his actions.

Respondents use scientific language to explain the causes of pornography addiction (that men's brains are "wired" in certain ways) and also the consequences of pornography addiction. Jesse (54, Protestant, CleanLife group leader) compares pornography to alcohol and cigarettes, making claims about health as a reason for avoiding pornography:

I don't think it's healthy. In the same way that alcohol, we call it becoming intoxicated, and of course it's taking a toxin into our body. I don't think there's a healthy level of 
cigarette smoking either. I don't really think that pornography is healthy for us. ... I just think there are people who are less likely to become addicted or to suffer the greater harm from it.

Kevin (35, Latter-day Saint, Nourish leader) agrees: "Porn is a public health crisis. Just like cigarettes were 40, 50 years ago, when they first made the link between cigarettes and lung cancer." Rather than focusing exclusively on religious guilt or shame, respondents like Jesse and Kevin pointed to the physical-and therefore objective-harms of pornography use.

Just as respondents used science to guide their religious response to men's pornography addiction, they also used religious beliefs to make sense of scientific claims. Participants who mentioned brain wiring also described how pornography "hijacks" God's natural design. Jonathan (19, Catholic, Nourish participant) puts this in explicitly religious language as he describes the temptation to watch pornography that comes directly from Satan: "Satan will tempt you into this and he will say, 'This is fine. You're good. You're not hurting anyone, ... and have a little fun with it, why don't you."' Nick (40, Latterday Saint, Nourish leader) uses scientific language to convey a similar message, explaining that the urge to watch pornography is a part of "natural impulses that are surrounded by synthetic sexuality." For both Jonathan and Nick, pornography is a secular and synthetic alteration of men's natural sexual impulses, which are both biologically and divinely created.

For individuals who believe that God is the creator of all living things, biological language about men and women's bodies, brains, and sexualities are simultaneously religious commentaries. Phil (42, Protestant), for example, is a longtime member and lay leader in a local chapter of Redeemed!, having attended his first meeting over a decade ago. For him, attending Redeemed! and other support groups made him realize that he is addictive and compulsive by nature, a nature that God designed. Redeemed! closely follows the 12-step program first created for AA. As in AA, attendees at Redeemed! introduce themselves by sharing names and admitting addiction. Phil shares how he introduces himself to the weekly group: 
I say, "my name is Phil. I'm a believer and I struggle with an addiction of pornography and video games." And I say it that way for me because I am a believer, that's my identity. My identity is not my addiction or my struggles. . . . My identity is in Christ, not in sin.

Phil's explanation of his group introduction reflects a broader trend in how respondents understand the blending of religion and science. They uniformly believe that pornography is a biological addiction, but they also believe that God created the biological human body. Therefore, respondents describe their faith in God as superseding and helping to overcome pornography addiction.

\section{Male and Female Bodies and "Opposite" Sexualities}

The religious and scientific schemas that interview respondents used to normalize pornography addiction did so specifically in relation to men, rather than women. These schemas thus do the work that Bridges and Pascoe (2014, 2018) describe as "fortifying boundaries" between men and women by entwining and conflating scientific and theological understandings of gender and sexuality. These boundaries thus appear fixed, restricting definitions to binary gender and making room for men to fully embody themselves as sexual beings, while pathologizing and isolating women who express interest in pornography.

One obvious way that pornography addiction recovery programs fortify boundaries between men and women is through gender-segregated support groups and curriculum. All programs in this study that used a group recovery model separated men from women. Twentyfive participants talked about gender segregation in their interviews, and most of them (18 of 25) believed separating groups by gender was the best model. These respondents explained their rationale with assumptions about gender difference and heterosexuality. First, many mentioned that differences between men and women would make a mixed-gender support group uncomfortable. Christopher puts it mildly, claiming that it would be "awkward" to admit his pornography addiction in front of women because he would be admitting to lusting after women. Expressing a similar sentiment, Brad (33, Protestant, 
CleanLife group leader), shares, “Frankly I just don't see guys opening up with a woman in the room. And I'm not even sure a woman would talk as vulnerable as they need to talk with a man in the room." Here, Brad signals that both men and women may have difficulty openly communicating with members of the "opposite" sex present.

Respondents also describe gender segregation as a way to protect men and women from men's heterosexual drives. Elliot explains,

I'd say I'd be very hesitant [to mix men and women] just based off being that vulnerable could be enticing, could be a temptation. When you're talking to women and getting that close, I'd say there's such a thing as a physical, emotional, and spiritual closeness that I can have with her, and if I'm being that emotional, I'd feel like there could be misconduct or I could favor some women because of my sexual attraction. So, I don't think it'd be a healthy idea for me to do it. But say I was healthy and I could maintain that, then I think it'd be okay but they'd be wondering why are you here.

Elliot positions himself, someone who struggles with pornography addiction, as "unhealthy" and therefore unable to maintain appropriate boundaries with women in an emotionally close support group such as True Intimacy. This mirrors broader public discussions that Westbrook and Schilt $(2014,48)$ call "penis panics" where women are positioned as inherently vulnerable and men, or more specifically bodies with penises, are seen as threatening in sexual spaces (or in this case, a group where sex is explicitly discussed). Elliot's commentary takes a turn by positioning "healthy" religious men as immune from penis panic, claiming these men are nonthreatening. Still, he points out the impossibility of this scenario because pornography addiction recovery groups are made up of "unhealthy" members.

Many men described religious settings as the only ones where they could discuss sex openly and seriously with one another. Indeed, these mirror Pascoe's (2007) observations of high school students' interactions where religious boys were the only group who did not participate in teasing and competition surrounding sex. Respondents often compared the emotional tenor of pornography addiction recovery groups to the churches and youth groups they grew up participating in that 
facilitated gender-specific programs for boys and girls. Jason recalls his church youth group as a teenager:

They would pretty much always have one night where they would split up guys and girls, and so the girls would have their talk about quote unquote "girl things" and us guys would have our "man talk" so to speak. And so, when it's a bunch of dudes talking about deeper struggles and those kinds of things, it's like the number one thing that was always talked about: sexuality and especially pornography. That was like always the number one thing talked about.

Mark (25, Protestant, Nourish participant) puts it this way, reflecting on entering high school when he first started watching porn: "It was kind of the popular sin to talk about just because you knew that it was something that every guy was struggling with." Bryan (22, Protestant, Nourish participant) shares a similar experience, describing how he and a group of other college-aged guys decided to create a summer bible study. During their first weekly meeting, Bryan learned that all of the guys in the group also struggled with pornography and so this became a frequent topic of conversation instead of or in addition to the Book of James they were studying. Experiences such as these normalize men's pornography use and fortify differences between men as sexual actors and women as those who are sexually acted upon.

When asked to elaborate on why respondents described pornography addiction as mostly a "man's problem," most described the reasons why women, they believe, do not look at pornography. Joe (31, Protestant, CleanLife group leader) references the "wiring" of men's brains to explain why men are more likely to use, and thus become addicted to, pornography:

I know that for men and women it's very different. Often for women it's hard to understand the nature of a man's brain and where it goes with these things and how much more difficult it can be for men. I don't think that it's more difficult for a man or a woman, but in my experience, the number seems to be typically quite a bit higher with men. I think that's just the way that, you know, we're wired sexually. 
Joe acknowledges that some women also struggle with pornography addiction, but then asserts that it is the biological make-up of men's bodies in particular that make pornography addiction more likely for them. Amber (24, Protestant, True Intimacy participant), who is the only woman respondent in our sample who personally struggles with pornography, says she found a small group for women "like her" and explains, "it just kinda comes down to the difference between how men and women are wired." She also notes, somewhat sarcastically, "Of course there isn't as much material for women, men are the ones to worry about. They're the ones wired for pornography addiction." Still, Amber believes that an addictive personality is in her "DNA" and says she is "definitely sexually aroused by the visual side of things." Most respondents, however, would describe Amber as atypical.

Though imagined as outliers, nearly all respondents made a point to mention the fact that "some" women struggle with pornography. These stories about women who are addicted to pornography further normalize men's pornography addictions, while isolating and pathologizing women. Jesse, a group leader, explains what he has observed from women who struggle with pornography compared with men: "We always find that these women had something happen to them when they were little," euphemistically suggesting that early experiences of abuse, violence, or some other form of victimization cause women to deviate from "normal" expressions of women's sexuality. Angela (39, Protestant) is a counselor who works in a nondenominational Protestant church and also leads a True Intimacy group. She explains, "I typically work with women. And, you know, so many times you're dealing with relational issues, but the women that I see who are the addicts often have, you know, the stereotypical kind of toxic childhood." Like Jesse, Angela does not specify details but makes clear that something interferes with women's normal sexual development when they become addicted to pornography.

Scientific and religious schemas are muddled together, as participants elaborate on the meaning of gender differences when it comes to pornography addiction. The dominant religious ideology of conservative Christianity-gender complementarianism-supposes that God created men and women (or males and females) to be distinct from one another in order to come together in marriage. This belief also supposes that God created men to be assertive, dominant, and leaders and women to be caretakers, helpers, and nurturers. Gender 
complementarianism reveals itself as respondents make claims about why men, rather than women, are more likely to be addicted to pornography. Frank (50, Protestant), who like Angela is a church-employed counselor and True Intimacy group leader, generalizes, "for the women ... . it's more the romance," suggesting that women do not get romantic or sexual fulfilment from pornography and that, when their husbands use it, the romance dies in their relationship. In this way, women are described as dependent on men for sexual attention and pleasure rather than as autonomous sexual actors. According to one woman, Deborah, women are more "relational" because "men will often connect in different ways, or for them connecting physically is more important, but for us [women], it's the emotional connection." Michael (20, Catholic, CleanLife leader) also believes that porn uniquely affects men physically, explaining that "men tend to masturbate more, I think, so they tend to watch more porn."

Both men and women fortify gender boundaries by claiming that women are emotional and relational whereas men are physical and visual. For men, drawing from religious and scientific schemas makes pornography addiction seem like a natural consequence of their bodies (God's creation) existing in a highly sexualized secular world. For women, because their bodies were created by God to be emotional, relational, and romantic, their attraction to pornography is a deviation from both theological and scientific understandings. Although discussions of the "hardwiring" of men's brains seem deterministic, they simultaneously allow greater flexibility when it comes to men's gender expressions and further emphasizes binary gender and heterosexuality as the natural order.

\section{Journey to a Redemptive Masculinity: The Religious Accomplishment of Recovery}

According to participants in pornography addiction recovery programs, men's biological bodies, unlike women's, explain their propensity to look at porn. These respondents understand religious commitment as the intervention that allows men to overcome their natural impulses. Secular culture, on the other hand, reinforces the relationship between normal men and pornography consumption. Mark makes this clear as he recalls being a teenager trying to understand social norms surrounding pornography: "If you were Christian you accepted 
that it was wrong. If you were not, it was totally fine." The prevailing secular attitude, as perceived by respondents, is that pornography is "not that big of a deal, everyone does it" (Travis), or put another way, most people "have accepted it [porn use] as normal" (Christopher). Religious commitment, therefore, serves to transform what may seem a subordinate form of masculinity (e.g., avoiding pornography) to align with hegemonic characteristics of self-control (see also Ezzell 2012) and that criticizes their secular porn-using counterpart as the weaker man.

Respondents commonly pitted religious values against secular ones. Eli, for example, who is one of two Jewish respondents in the sample and a member of the secular program, Nourish, describes himself as being more committed to religious teachings than the rest of his family. He shares that when he was a teenager, his shame and guilt motivated him to disclose to his father that he had looked at pornography. Expecting to be reprimanded, he was surprised by his father's response:

I spoke to my dad and I told him about it, and I said that this really bothers me that I do this [look at pornography]. And then he gave me this whole talk saying, "I really hear you and understand what you're saying, but, at the same time, it's also normal. You're a normal functioning teenager."

Eli goes on to describe how he felt relieved that his father was not angry with him, but then asserts how even though he believes looking at pornography is "natural," he refused to agree with his father that it is "normal." The reason, he explains, is "I don't believe that this is what God intended." Eli was similar to other respondents who noted it was their religious beliefs that made them unique in their attitudes opposing pornography.

Even though men's consumption of pornography is an expectation of hegemonic masculinity, religious respondents discursively construct quitting porn as a hard-won achievement and thus an alternative assertion of masculinity. Jonathan answers the question about why he decided to join a pornography recovery support program this way: "Because I was tired of being held down by the chains of pornography. I was tired of not being who I am meant to be and not being the person that God made me to be more importantly." Secular men, Jonathan 
implies, will continually be "held down" by pornography because they do not have faith in God. These men are not in control, whereas Jonathan, with the help of God, is. For Derek (27, Catholic, Nourish participant), it was by framing his pornography use as a "fight" that changed his father's perception:

At first it was more of a shame, guilt, "I caught you" kind of thing. But that developed and I think he became more understanding as I started to do these kinds of programs and really confiding to him, like, "this is a problem and I don't want this," and I really am fighting it. And he would see that, you know, I'm a faithful man who really does want to respect women and live a full life and he came to be more sympathetic towards it, or empathetic, towards seeing that and wanting to encourage me in growing out of it.

By emphasizing his efforts at recovery, Derek transformed his father's reaction from shameful reprimand to compassion and sympathy. By discursively distancing religious men from their secular counterparts, narratives about pornography addiction recovery become religiously affirming.

Though all participants describe their ultimate goal as living a life where they never consume pornography, most described a back and forth of victory and failure as part of the process. Brad, an online group leader, describes it as a "journey," saying his intention is to "journey with" the men in his group by offering "unconditional love." He explains that men's hearts are more important than whether they succeed or fail when it comes to looking at pornography. When asked what recovery looked like for them, men typically described their "journey" as one where they mostly abstained from pornography but experienced occasional "setbacks," "relapses,” or "binges.” Jonathan, who above described wanting to break free from the "chains of pornography," admits that he still typically watches pornography once or twice a month. He reflects, "I can't beat myself up over every little failure. I have to celebrate the successes as well.” By emphasizing his persistent faith in God, Jonathan situates both abstaining and indulging in pornography as part of his Christian journey.

Religious commitment sets up validation for religious men regardless of whether or not they successfully avoid pornography, because 
they uniquely have access to a God who can offer them redemption. Mark, like Jonathan above, also acknowledges occasional "failures" but says he focuses on his successes. He uses a tool from Nourish's selfled program that tracks percentages of days each month where users report that they do not look at pornography. "It's changing the perspective from a shame focus of every time I have a setback I just kind of feel like I failed and I'm back to ground zero. And the nice thing about it was I was able to visualize that there were way more victorious days than there were days that I had a setback." Mark is able to overcome what he calls a "shame focus" because of his faith in God. Because respondents understand pornography addiction as a result of all men's biologically and divinely created sexual drives, respondents describe religious men as having unique access to redemptive masculinity and in turn emphasize religious men's agency, autonomy, and accomplishments.

\section{Conclusion}

In this article, we analyze narratives from religious participants of pornography addiction recovery programs to argue that pornography addiction is an illustrative example of hybrid masculinity. We use a cultural approach that emphasizes how shared beliefs and values, or schemas, provide explanation and justification for men's behaviors and choices. Respondents in pornography addiction recovery programs draw from religious and scientific schemas to explain why they believe it is normal and natural for men, rather than women, to look at pornography. Their stories of "fighting the battle" against pornography cement pornography addiction recovery as a masculine effort, what we call redemptive masculinity. This hybrid form of masculinity allows men to navigate the constraints of religious manhood in ways that support their religious beliefs that oppose pornography consumption, while simultaneously supporting hegemonic masculine expectations that men look at porn.

Pornography addiction recovery programs offer a useful example of how hybrid masculinities draw from essentialist and categorical gender beliefs (Messner 2011) to perpetuate (1) gender inequality, (2) the relationship between gender and heterosexuality, and (3) hierarchies among men. First, we find that redemptive masculinity maintains a 
gender hierarchy based on biological and religious understandings of gender essentialism. Narratives surrounding pornography addiction reflect broader norms within conservative religious communities where women's sexuality is stifled or stigmatized (Burke 2016; Diefendorf 2015). As Perry (2019, 91) has observed, conservative Protestants understand women who look at pornography to be "sinning against their gender, or sinning like a man." Respondents in this study acknowledge that some women use and become addicted to pornography, but these women are said to have experienced past abuse or trauma that fueled their gender-deviant interest in porn. Men who become addicted to pornography, on the other hand, are said to be responding to their natural sexual urges. These narratives place men's and women's sexualities on distinct and uneven trajectories, giving room for normative and agentic understanding of men's sexual desires and behaviors while pathologizing and limiting women's.

Second, we have shown how hybrid masculinity contributes to what Steven Seidman (1995) calls the sex/gender/sexuality system, bolstering how these categories overlap and depend on one another. We find that religious narratives blend scientific and theological understandings of sex (that God created biological differences between male and female bodies) to embolden claims about gender difference (that it is normal for men to want look at pornography, while it is abnormal for women to want to look at pornography) that then reinforce ideas about heterosexuality as innate and deterministic (these sex/gender differences exist ultimately because men and women complement one another). The sex/gender/sexuality system supported by religious beliefs then serves as a kind of safety net for hybrid masculinities, where greater flexibility is possible for individuals who conform to normative expectations surrounding sex, gender, and heterosexuality.

Finally, our analysis expands on existing research that finds pornography consumption is damaging to religious men because they experience moral incongruence (Grubbs and Perry 2019). To the contrary, the stories presented in this article suggest that some religious men who experience shame or guilt as a result of what they believe is their natural sexual desire to view pornography may use these experiences as reintegrative rather than permanently stigmatizing within a religious community that opposes pornography. In the Christian tradition, redemption from sin has long been a key trope in salvation narratives. Redemption is granted by God, but also requires a human actor 
to commit to and accept God's offering. In turn, redemptive masculinity is both a religious practice and demonstration of men's agency (see also Clark 2010; Flores 2014). It is a therapeutic project with a goal of self-transformation and acceptance (see also Pfaffendorf 2017, 2019). But it is possible only in the context of intersecting privileges. Because of their privileges as white, cisgender, mostly straight and mostly Christian, religious men in pornography addiction recovery programs can admit to being "powerless" over their pornography addiction without actually losing their positions of power. They are unlikely to be stigmatized for dangerous sexual excess-as black and/or gay men would (Collins 2004; Mosse 1996). Instead, their stories affirm their manhood, bolster their religious legitimacy, enhance their sense of agency and accomplishment, and secure their positions of privilege. A critical analysis thus reveals how the narratives of pornography addiction recovery protect the interests and sexual expression of white, heterosexual men (religious and secular) as the primary consumers of pornography, even while condemning the practice.

Acknowledgments - This research was partially supported by the University of Nebraska-Lincoln Behavioral Health Program of Excellence, the University of Nebraska Lincoln College of Arts and Sciences ENHANCE Faculty Research Grant, and the University of Nebraska Lincoln Department of Sociology USTAR program. We thank Tristan Bridges, Amy McDowell, and Dawne Moon for their support and feedback on this article, and Claire Bartels, Jordan Malzer, and Nick Martinez for their research assistance.

\section{References}

American Psychiatric Association. 2013. Diagnostic and statistical manual of mental disorders, 5th ed. Washington, DC: American Psychiatric Association.

Barber, Kristen. 2016. Styling masculinity: Gender, class, and inequality in the men's grooming industry. New Brunswick: Rutgers University Press.

Blair-Loy, Mary. 2001. Cultural constructions of family schemas: The case of women finance executives. Gender \& Society 15 (5): 687-709.

Bradley, David F., Joshua B. Grubbs, Alex Uzdavines, Julie J. Exline, and Kenneth I. Pargament. 2016. Perceived addiction to internet pornography among religious believers and nonbelievers. Sexual Addiction \& Compulsivity 23 (2/3): 225-43.

Bridges, Tristan. 2014. A very "gay" straight? Hybrid masculinities, sexual aesthetics, and the changing relationship between masculinity and homophobia. Gender \& Society 28 (1): 58-82. 
Bridges, Tristan. Forthcoming. White masculine privilege as stigmatizing? On (anti)feminist men's construction of white men as collectively disadvantages. Signs: Journal of Women in Culture.

Bridges, Tristan, and C. J. Pascoe. 2014. Hybrid masculinities: New directions in the sociology of men and masculinities. Sociology Compass 8 (3): 246-58.

Bridges, Tristan, and C. J. Pascoe. 2018. On the elasticity of gender hegemony: Why hybrid masculinities fail to undermine gender and sexual inequality. In Gender reckonings: New social theory and research, edited by James Messerschmidt, Patricia Yancey Martin, Michael Messner, and Raewyn Connell. New York: New York University Press.

Burke, Kelsy. 2016. Christians under covers: Evangelicals and sexual pleasure on the Internet. Berkeley: University of California Press.

Burke, Kelsy, and Amy Moff Hudec. 2015. Sexual encounters and manhood acts: Evangelicals, latter-day saints, and religious masculinities. Journal for the Scientific Study of Religion 54 (2): 330-44.

Clark, Robert Lewis. 2010. Punks, snitches, and real men: Negotiations of masculinity and rehabilitation among prison inmates. Theory in Action 3 (3): 63-97.

Collins, Patricia Hill. 2004. Black sexual politics: African Americans, gender, and the new racism. New York: Routledge.

Connell, Raewyn. (1987) 2005. Gender and power: Society, the person, and sexual politics. Stanford: Stanford University Press.

Connell, Raewyn, and James W. Messerschmidt. 2005. Hegemonic masculinity: Rethinking the concept. Gender \& Society 19 (6): 829-59.

Corbin, Juliet, and Anselm Strauss. 2007. Basics of qualitative research: Techniques and procedures for developing grounded theory, 3rd ed. Thousand Oaks: Sage.

Demetrieu, Demetrakis Z. 2001. Connell's concept of hegemonic masculinity: A critique. Theory and Society 30 (3): 337-61.

DeRogatis, Amy. 2015. Saving sex: Sexuality and salvation in American Evangelicalism. New York: Oxford University Press.

Diefendorf, Sarah. 2015. After the wedding night: Sexual abstinence and masculinities over the life course. Gender \& Society 29 (5): 647-69.

Ezzell, Matthew B. 2012. "I'm in control": Compensatory manhood in a therapeutic community. Gender \& Society 26 (2): 190-215.

Fefferman, Ann M., and Ushma D. Upadhyay. 2018. Hybrid masculinity and young men's circumscribed engagement in contraceptive management. Gender \& Society 32 (3): 371-94.

Flores, Edward Orozco. 2014. God's gangs: Barrio ministry, masculinity, and gang recovery. New York: New York University Press.

Garlick, Steve. 2010. Taking control of sex? Hegemonic masculinity, technology, and Internet pornography. Men and Masculinities 12 (5): 597-614.

Gerber, Lynne. 2016. Grits, guts, and vanilla beans: Godly masculinity in the exgay movement. Gender \& Society 29 (1): 26-50. 
Grubbs, Joshua B., and Samuel L. Perry. 2019. Moral incongruence and pornography use: A critical review and integration. Journal of Sex Research 56 (1):

29-37.

Grubbs, Joshua B., Shane W. Kraus, and Samuel L. Perry. 2019. Self-reported addiction to pornography in a nationally representative sample: The roles of use habits, religiousness, and moral incongruence. Journal of Behavioral Addictions 8 (1): 88-93.

Harding, David J. 2010. Living the drama: Community, conflict, and culture among inner-city boys. Chicago: University of Chicago Press.

Heath, Melanie. 2019. Espousing patriarchy: Conciliatory masculinity and homosocial femininity in religiously conservative families. Gender \& Society 33 (6): 888-910.

Hughey, Matthew W. 2010. The (dis)similarities of white racial identities: The conceptual framework of "hegemonic whiteness." Ethnic and Racial Studies 33 (8): 1289-309.

Irvine, Janice M. (1990) 2005. Disorders of desire: Sex and gender in modern American sexology. Philadelphia: Temple University Press.

Johansson, Thomas, and Nils Hammarén. 2007. Hegemonic masculinity and pornography: Young people's attitudes toward and relations to pornography. Journal of Men's Studies 15 (1): 57-70.

Lorber, Judith. 1994. Paradoxes of gender. New Haven: Yale University Press.

McDowell, Amy D. 2017. Aggressive and loving men: Gender hegemony in Christian hardcore punk. Gender \& Society 31 (2): 223-44.

Messner, Michael. 2011. Gender ideologies, youth sports, and the production of soft essentialism. Sociology of Sport Journal 28 (2): 151-70.

Messner, Michael A., and Suzel Bozada-Deas. 2009. Separating the men from the moms: The making of adult gender segregation in youth sports. Gender \& Society 23 (1): 49-71.

Moon, Dawne, and Theresa W. Tobin. 2018. Sunsets and solidarity: Overcoming sacramental shame in conservative Christian churches to forge a queer vision of love and justice. Hypatia 33 (3): 451-68.

Mosse, George L. 1996. The image of man: The creation of modern masculinity. New York: Oxford University Press.

Netherland, Julie. 2012. Introduction: Sociology and the shifting landscape of addiction. In Critical perspectives on addiction, edited by Julie Netherland. Bingley, UK: Emerald.

Oeming, Madita. 2018. A new diagnosis for old fears? Pathologizing porn in contemporary U.S. discourse. Porn Studies 5 (2): 213-17.

Oeur, Freeden Blume. 2018. Black boys apart: Racial uplift and respectability in all-male public schools. Minneapolis: University of Minnesota Press.

Pascoe, C. J. 2007. Dude, you're a fag: Masculinity and sexuality in high school. Berkeley: University of California Press. 
Patterson, Orlando. 2014. Making sense of culture. Annual Review of Sociology 40: $1-30$.

Perry, Samuel L. 2019. Addicted to lust: Pornography in the lives of conservative Protestants. New York: Oxford University Press.

Pfaffendorf, Jessica. 2017. Sensitive cowboys: Privileged young men and the mobilization of hybrid masculinities in a therapeutic boarding school. Gender \& Society 31 (2): 197-222.

Pfaffendorf, Jessica. 2019. Wayward elites: From social reproduction to social restoration in a therapeutic boarding school. Social Psychology Quarterly 82 (2): $113-33$.

Pugh, Allison J. 2013. What good are interviews for thinking about culture? Demystifying interpretive analysis. American Journal of Cultural Sociology 1 (1): 42-68.

Randles, Jennifer. 2018. "Manning up" to be a good father: Hybrid fatherhood, masculinity, and U.S. responsible fatherhood policy. Gender \& Society 32 (4): 516-39.

Ridgeway, Cecilia L., and Shelley J. Correll. 2004. Unpacking the gender system: A theoretical perspective on gender beliefs and social relations. Gender \& Society 18 (4): 510-31.

Rios, Victor M. 2011. Punished: Policing the lives of Black and Latino boys. New York: New York University Press.

Schmitz, Rachel M., and Trenton M. Haltom. 2017. "I wanted to raise my hand and say I'm not a feminist": College men's use of hybrid masculinities to negotiate attachments to feminism and gender studies. Journal of Men's Studies 25 (3): 278-97.

Seidman, Steven. 1995. Deconstructing queer theory or the under-theorization of the social and the ethical. In Social postmodernism: Beyond identity politics, edited by Linda J. Nicholson and Steven Seidman. Cambridge, UK: Cambridge University Press.

Stoops, Jamie. 2017. Just like heroin: Science, pornography, and heteronormativity in the virtual public sphere. Porn Studies 4 (4): 1-17.

Sumerau, J. Edward. 2012. "That's what a man is supposed to do": Compensatory manhood acts in an LGBT Christian church. Gender \& Society 26 (3): 461-87.

Swidler, Ann. 1986. Culture in action: Symbols and strategies. American Sociological Review 51 (2): 273-86.

Thomas, Jeremy N. 2013. Outsourcing moral authority: The internal secularization of evangelicals' anti-pornography narratives. Journal for the Scientific Study of Religion 52 (3): 457-75.

Travis, Trysh. 2009. The language of the heart: A cultural history of the recovery movement from alcoholics anonymous to Oprah Winfrey. Chapel Hill: University of North Carolina Press.

Vaisey, Stephen. 2009. Motivation and justification: A dual-process model of culture in action. American Journal of Sociology 114 (6): 1675-715. 
Voros, Florian. 2009. The invention of addiction to pornography. Sexologies 18 (4): $243-46$.

Wagner, Melinda Bollar. 1997. Generic conservative Christianity: The demise of denominationalism in Christian schools. Journal for the Scientific Study of Religion 36 (1): 13-24.

Waidzunas, Tom. 2015. The straight line: How the fringe science of ex-gay therapy reoriented sexuality. Minneapolis: University of Minnesota Press.

Westbrook, Laurel, and Kristen Schilt. 2014. Doing gender, determining gender: Transgender people, gender panics, and the maintenance of the sex/gender/ sexuality system. Gender \& Society 28 (1): 32-57.

Weinberg, Darin. 2002. On the embodiment of addiction. Body \& Society 8 (4): 1-19.

Winant, Howard. 2004. The new politics of race: Globalism, difference, justice. Minneapolis: University of Minnesota Press.

\section{$\diamond \diamond \diamond \diamond$}

Kelsy Burke is Assistant Professor of Sociology at the University of NebraskaLincoln where she researches the intersection of conservative Christianity, gender, and heterosexuality within contemporary American culture and politics. Her first book is Christians under Covers: Evangelicals and Sexual Pleasure on the Internet (2016, University of California Press).

Trenton M. Haltom is a PhD Candidate in Sociology at the University of Nebraska-Lincoln. His research focuses on men's "crises" of gender and sexuality across media, occupations, health, or sports. His dissertation is a mixed-methods content analysis of representations of men's bodies in popular U.S. magazines over time. 